\title{
Effects of manual brushing on 10-year survival and growth of Douglas-fir in the mixed broadleaf - shrub complex of southern interior British Columbia
}

\author{
by George Harper ${ }^{1, *}$ and Kevin Brown ${ }^{2}$
}

\begin{abstract}
Manual brushing is used to minimize the competitive effects of paper birch (Betula papyrifera Marsh) and associated broadleaved trees on young Douglas-fir (Pseudotsuga menziesii var. glauca) in southern interior British Columbia. Effects of brushing broadleaved trees, predominantly birch, on interior Douglas-fir survival and growth were studied on four sites. Treatments were applied when plantations were five to nine years old. Through 10 years post treatment, brushing did not affect Douglas-fir survival, but increase height by $22 \%$ and stem diameter by $31 \%$ and the differences were greater than seen at five years. After 10 years, linear models described a declining Douglas-fir height or diameter with increasing broadleaved tree density. Boundary line analysis was used to describe maximum treatment response to broadleaved density and two distance independent competition indices for birch and broadleaves, combining either cover or density with relative heights ( $\mathrm{CRH}, \mathrm{DRH}$, respectively). A negative exponential relationship was fit to 10-year Douglas-fir heights and diameters with increasing values CRH or DRH. Competition thresholds for density, CRH and DRH were not apparent. The quantile regression results indicated the 10-year response of young Douglas-fir diameter to brushing occurred primarily with the largest $55 \%$ to $85 \%$ of the population, CRH and DRH respectively.
\end{abstract}

Keywords: Douglas-fir plantations, broadleaved vegetation, manual brushing, survival, height growth, diameter growth

\section{RÉSUMÉ}

Le débroussaillage manuel permet de minimiser la compétition exercée par le bouleau à papier (Betula papyrifera Marsh) et les autres essences feuillues compagnes sur les jeunes plants de sapin de Douglas (Pseudotsuga menziesii var. glauca) dans l'intérieur sud de la Colombie-Britannique. Nous avons étudié l'effet qu'avait le débroussaillage des feuillus, surtout le bouleau blanc, sur la survie et la croissance du sapin de Douglas sur quatre sites. Les traitements ont été effectués dans des plantations de cinq à neuf ans. Dix ans après le traitement, le débroussaillage n'a pas eu d'effet sur la survie du sapin de Douglas, mais a permis d'accroître sa hauteur de $22 \%$ et son diamètre de $31 \%$ et les différences étaient plus marquées que celles observées après cinq ans. Après dix ans, les modèles de régression linéaires prévoyaient une réduction de la hauteur ou du diamètre chez le sapin de Douglas à mesure qu'augmentait la densité des feuillus. On a eu recours à l'analyse des valeurs limites pour décrire la réaction maximale au traitement selon la densité des feuillus et pour calculer les indices de compétition sans égard à la distance pour le bouleau et les feuillus combinant le couvert ou la densité et hauteur relative (respectivement $\mathrm{CRH}$ et $\mathrm{DRH}$ ). On a pu mettre en évidence une relation exponentielle négative entre la hauteur et le diamètre du sapin de Douglas (après dix ans) et l'accroissement de CRH ou de DRH. Toutefois, il ne semblait pas y avoir de seuils pour la densité d'après les indices $\mathrm{CRH}$ et $\mathrm{DRH}$. Les résultats de la régression quantile ont montré qu'après dix ans, la réponse en diamètre des jeunes sapins de Douglas au débroussaillage se manifestait principalement dans la majeure partie de la population, soit $55 \%$ et $85 \%$ pour les indices CRH et DRH respectivement.

Mots-clés : plantation de sapin de Douglas, végétation feuillue, débroussaillage manuel, survie, croissance en hauteur, croissance en diamètre

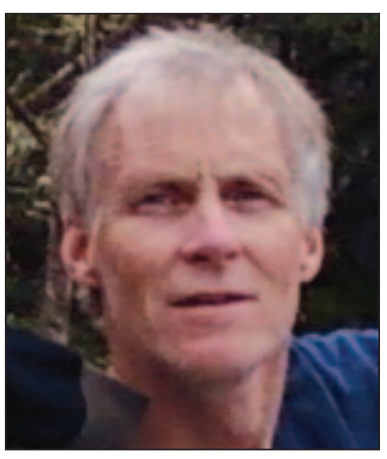

George Harper

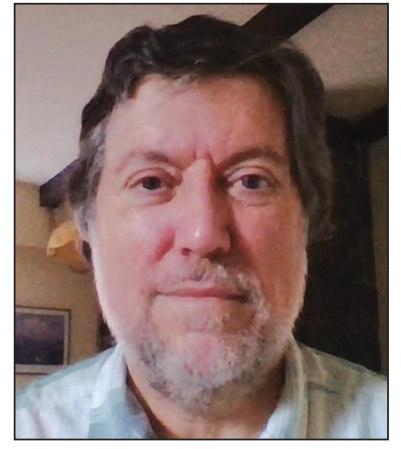

Kevin Brown
${ }^{1}$ Ministry Forests, Lands, Natural Resource Operations and Rural Development, Resource Practices Branch, Victoria, British Columbia; ${ }^{\star}$ correspondence: George.Harper@gov.bc.ca ${ }^{2}$ KR Brown and Associates, Victoria, British Columbia 


\section{Introduction}

Interior Douglas-fir (Pseudotsuga menziesii [Mirb.] Franco) often dominates low- and mid-elevation forests of southern interior British Columbia and has long been important commercially because of its wood properties and availability. Following harvest, deciduous broadleaved species, particularly paper birch (Betula papyrifera Marsh), trembling aspen (Populus tremuloides Michx.), and black cottonwood (Populus balsamifera L. ssp. trichocarpa T. \& G.) may regenerate prolifically, grow rapidly and compete for limited resources with Douglas-fir and other commercially important conifers (Peterson et al. 1997). Cutting of deciduous broadleaved trees, typically by mechanical brushing (Comeau et al. 1999), is often employed to ensure adequate growth of planted conifers, generally five to 15 years after plantation establishment (Baleshta et al. 2015). Despite the expense of mechanical brushing, complete removal is favored over partial removal because it minimizes the costly risk to companies of not meeting free growing reforestation standards (Newsome et al. 2012; Coates and Lilles 2013, BC MFLNRO 2015).

Resource requirements and growth rates of trees vary with species; deciduous broadleaved trees native to British Columbia are often associated with wetter and more fertile habitats (Waring and Franklin 1979; Klinka et al. 1990) and may respond more to increased availability of nutrients, moisture and light, when young, than do their coniferous associates (e.g., Chapin et al. 1983; Brown 1999). This implies that levels of competing trees (e.g., deciduous broadleaved) appropriate for maintaining adequate growth of the commercial species will vary with the site and species. These relations cannot easily be assessed at a stand level, given variability in microsites and abundance of competing vegetation and given operational and financial constraints in establishing and maintaining long-term experiments. One approach is to assess individual crop tree responses to abundance of competing vegetation within a "competitive neighborhood", an approach consistent with determination of reforestation success as described by "free-to-grow" and stocking standards (Burton 1993, BC MOF 2007; Appendix 9). Based on this approach, "competition thresholds" have been estimated, where crop tree growth is independent of vegetation competition below the threshold and dependent above the threshold (Wagner et al. 1989; Simard et al. 2001; Heineman et al. 2009). In theory, competition thresholds may be used to guide competing vegetation removal to promote maximum crop tree growth (Wagner 2000).

In southern BC, paper birch dominates the Mixed Broadleaf-Shrub Vegetation Complex, associated with early successional stands on moist, well-drained, medium to rich sites in the Interior Douglas-fir (IDF) and Interior cedarhemlock (ICH) biogeoclimatic zones of British Columbia (Meidinger and Pojar 1991, Simard et al. 2001). Birch may regenerate rapidly from seed or stump sprouts if harvesting removes the canopy and exposes mineral soil (Peterson et al. 1997). This makes birch a significant competitor to planted Douglas-fir, the impact of which is greatest in younger stands (Simard et al. 2004). Reducing birch densities has been shown to increase Douglas-fir growth (Simard 1990; Simard et al. 2001; Baleshta et al. 2005, 2015), however, brushing treatments may increase infection rates by Armillaria ostoyae (Romagn.) Herink, increase mortality of Douglas-fir
(Baleshta et al. 2005) and decrease the diversity of cryptogams (Baleshta et al. 2015). Retention of broadleaf stems has been suggested to improve crop tree health, soil productivity, community diversity and habitat (Coates and Lilles 2013, Baleshta et al. 2015). A greater understanding of the competitive relations between Douglas-fir and birch (and broadleaf trees in general) is required to improve site management prescriptions. This includes long term monitoring of crop tree and competing species responses over a range of competing species abundance on a variety of sites.

In 1993, an experimental program was established across 96 operational cutblocks in southern interior British Columbia to examine: (1) the effects of brushing treatments on planted conifers and associated competing vegetation in a variety of ecosystems and vegetation complexes; and, (2) within sites and vegetation complexes, determine how crop trees responded to a range of competing vegetation abundances (Simard 1993). In this paper, we report 10-year responses of Douglas-fir to manual brushing in the birchdominated Mixed Broadleaf-Shrub Vegetation Complex of the IDF and ICH biogeoclimatic zones. Five-year responses on a subset of the study sites have been reported earlier (Simard et al. 2001). The objectives were to assess manualbrushing treatment effects after 10 years on survival, vigor, and growth of Douglas-fir and abundance of targeted vegetation and, to determine how Douglas-fir growth varied with abundance of neighboring broadleaf trees.

\section{Methods}

Four study sites were selected (Enterprise Creek, Mabel Lake, Johnson Lake and Champion Creek), one located in the IDF and three in the ICH (Table 1). All four sites had been clearcut (1981 to 1990) and planted with Douglas-fir (PSB 313 1+0 containerized seedlings). Silviculture surveys indicated a similar vegetation complex had established at each site, the Mixed Broadleaf-Shrub Vegetation Complex (Simard et al. 2001). Site elevation ranged from 450 to $1200 \mathrm{~m}$ and slopes ranged from $10 \%$ to $45 \%$ with north to northwest aspects. Sites were classified as mesic and soils were noted as either sandy loam or silt loam. Plantation age at time of manual brushing ranged from five to nine years. Paper birch was the predominant deciduous broadleaved species found on each site.

The study used a randomized complete block design, with each site representing one block. Within each site, two treatments (untreated control and manual brushing) were randomly assigned to two 0.8 ha plots. All broadleaf stems were cut near ground level using motorized tools completed by operational crews as part of the research-based evaluation program known as the Protocol for Operational Brushing Evaluations or PROBE (Simard 1993; Simard et al. 2001). Within each plot, 36 subplots $(6 \times 6$ grid points at $10 \mathrm{~m}$ intervals) were systematically located within the $50 \times 50 \mathrm{~m}$ measurement area surrounded by $20 \mathrm{~m}$ buffer zones. At each grid point the nearest Douglas-fir ("target crop tree") was selected for measurement. Plot establishment, target crop tree and non-crop vegetation assessments followed the Simard (1993) protocol. All grid points were permanently marked, and target crop trees were stem mapped and tagged.

Measurements occurred immediately before brushing (year 0 ) and at 1, 3, 5, and 10 years thereafter. Repeated measurements of crop trees consisted of survival, height, current- 
Table 1. Characteristics and treatments at the four sites (adapted from Simard et al. 2001). DB refers to deciduous broadleaved trees

\begin{tabular}{|c|c|c|c|c|c|c|c|c|c|c|}
\hline Site location & $\begin{array}{c}\text { BEC } \\
\text { variant }^{\mathrm{a}}\end{array}$ & $\begin{array}{l}\text { Elevation } \\
\quad(\mathrm{m})\end{array}$ & $\begin{array}{l}\text { Aspect/ } \\
\text { slope (\%) }\end{array}$ & $\begin{array}{c}\text { Soil } \\
\text { texture }\end{array}$ & $\begin{array}{c}\text { Year } \\
\text { har- } \\
\text { vested/ } \\
\text { planted }\end{array}$ & $\begin{array}{c}\text { Age at } \\
\text { treatment } \\
\text { (years) }\end{array}$ & $\begin{array}{l}\text { Treat- } \\
\text { ment } \\
\text { date }\end{array}$ & $\begin{array}{c}\text { Initial } \\
\text { cover }(\%) \\
\text { Birch }\end{array}$ & $\begin{array}{c}\text { Initial } \\
\text { cover (\%) } \\
\text { all DB } \\
\text { trees }\end{array}$ & $\begin{array}{c}\text { Initial } \\
\text { DB } \\
\text { density } \\
\text { (sph) }\end{array}$ \\
\hline Enterprise Creek, Lillooet & IDFdk2 & 950 & $\mathrm{~N} / 45$ & sandy loam & $1981 / 86$ & 5 & Oct 1991 & 15.1 & 17.3 & 4824 \\
\hline Mabel Lake, Vernon & ICHmw2 & 450 & NW/35 & sandy loam & $1983 / 87$ & 8 & Aug 1991 & 7.4 & 8.2 & 5381 \\
\hline Johnson Lake, Kamloops & ICHmk1 & 1200 & $\mathrm{~N} / 10$ & sandy loam & $1981 / 86$ & 5 & Jul 1993 & 19.8 & 23.5 & 21500 \\
\hline $\begin{array}{l}\text { Champion Creek, } \\
\text { Castlegar }\end{array}$ & ICHdw & 880 & $\mathrm{~N} / 25$ & silt loam & $1990 / 92$ & 9 & Aug 2001 & 24.3 & 26.6 & 4785 \\
\hline
\end{tabular}

aBiogeoclimatic ecosystem classification (BEC)

year leader length, basal stem diameter, crown length and crown width; from these, live crown ratio (live crown length/tree height), individual tree stem volume (volume of a cone), and height: diameter ratios were calculated. Tree vigor (good, moderate or poor) and damage causes were visually assessed, as was competitive status (overtopped, threatened, and free to grow) (Simard 1993). Overtopped status was defined as having a leader overtopped by surrounding vegetation. Threatened status indicates crop tree height was equivalent to the height of surrounding vegetation and is likely to become overtopped within two growing seasons. Free to grow status means leaders of crop trees are well above the surrounding vegetation; these trees are expected to remain unthreatened. Vegetation percent cover (visually estimated to the nearest 5\%) and modal height (the most frequent height of all individuals, estimated to the nearest 10 $\mathrm{cm}$ ) were determined in $2.52 \mathrm{~m}$ radius $\left(20 \mathrm{~m}^{2}\right)$ subplots around each target tree (Simard 1993) for the following vegetation types: all species combined, all broadleaved tree species combined (primarily paper birch, trembling aspen and black cottonwood), all shrubs, all herbs, and the target species paper birch. In year 10, the cover and numbers of birch and all broadleaved trees were determined in $3.99 \mathrm{~m}$ radius $\left(50 \mathrm{~m}^{2}\right)$ subplots around each target tree.

Effects of brushing were analyzed for individual years by analysis of variance (ANOVA). Plot means were the experimental units and the blocks (site) $\mathrm{x}$ treatment mean squares were the error terms. Response data were transformed as necessary to satisfy assumptions of normality and homogeneity of variance: natural log-transformations (Ln) used for growth and cover data and arcsine square root transformations for percentage (survival and cover) data. Statistical analysis was performed with SAS (version 9.4 and JMP version 3.1, SAS Institute Inc. Cary, NC).

Relationships between Douglas-fir heights or diameters and abundance of birch or all deciduous broadleaved trees were examined for year 10 data using scatter plots and regression analyses of data from pooled site $\mathrm{x}$ treatment subplots (up to $\mathrm{n}=144$ subplots per treatment). Competing vegetation abundance was quantified as broadleaf tree density (stems per hectare) or as one of two distance independent competition indices as described in Simard et al. (2001):

$$
\begin{aligned}
& \text { Cover-Relative Height }(\mathrm{CRH})=\mathrm{C} \times \mathrm{R} / \mathrm{H} \text { and, } \\
& \text { Density-Relative Height }(\mathrm{DRH})=\mathrm{D} \times \mathrm{R} / \mathrm{H}
\end{aligned}
$$

where, $\mathrm{C}$ and $\mathrm{D}$ are cover (\%) or stem count of the competing vegetation (stems per hectare (sph)), respectively, in each subplot and $\mathrm{R}$ and $\mathrm{H}$ are the modal heights of the competing vegetation and height of the target conifer, respectively.

The relationships between Douglas-fir growth and abundance of all deciduous broadleaved (DB) trees present are emphasized in this paper.

Inspections of scatter plots indicated that Douglas-fir growth varied greatly at lower abundances of competing vegetation both within and across sites. Consequently, boundary lines were fit to the upper boundary of each scatter plot to define the growth constraint imposed by competing vegetation (e.g., Wagner et al. 1989). This approach defines the highest presumed attainable growth in relation to the independent variable (competing vegetation abundance) and assumes that factors other than abundance of competing vegetation (e.g., microsite characteristics; herbivory) are responsible for reducing growth below the maximum. Boundary line analysis has been used to assess effects of resource availability on crop yield (e.g., Sadras et al. 2015) and tree growth (e.g., Harrington and Courtin 1994). To determine the boundary line, we divided the vegetation abundance data into equivalent classes of equal sized interval or, equal number of trees. The largest $y$ value in each class was selected and a regression line was fit to that subset of data (using the $x$ value associated with the maximum $y$ ). This binning approach was arbitrary; the size of each $\mathrm{x}$ variable interval, the number of intervals or number of trees was a compromise between minimizing the frequency of outliers and capturing the shape of the curve. In addition, quantile regression (Koenker and Bassett 1978) using a linearized type 1 exponential function (Sit and Poulin-Costello 1994) was used to define the response distribution of Douglas-fir size with competition intensity (SAS; proc quantreg). Estimated quantile regression parameters for intercept, slope and brushing treatment difference, by quantile level with $95 \%$ confidence limits, provided additional evidence of brushing treatment effects on Douglas-fir size. Even though quantile regression makes 
Table 2. Survival and size of Douglas-fir in control (C) and brushed (BR) plots $0,1,3,5$, and 10 years after treatment. Values shown are least squares means (+ s.e.) of untransformed data and probability ( $P$ values) for treatment effect; *indicates $P$ value for Ln-transformed data. $P$ values $\leq 0.05$ bolded. Crown length and crown width data are not shown for years 0 and 1 , as data were collected at only one and two sites, respectively

\begin{tabular}{|c|c|c|c|c|c|c|c|c|c|c|}
\hline Year & TREAT & $\begin{array}{c}\text { Survival } \\
(\%)\end{array}$ & $\begin{array}{c}\text { Height } \\
(\mathrm{cm})\end{array}$ & $\begin{array}{l}\text { Diameter } \\
\quad(\mathrm{cm})\end{array}$ & $\begin{array}{c}\text { Leader } \\
\text { length } \\
(\mathrm{cm})\end{array}$ & $\begin{array}{c}\text { Crown } \\
\text { width } \\
(\mathrm{cm})\end{array}$ & $\begin{array}{c}\text { Crown } \\
\text { length } \\
(\mathrm{cm})\end{array}$ & $\begin{array}{c}\text { Crown } \\
\text { length } \\
(\%)\end{array}$ & $\begin{array}{c}\text { Height/ } \\
\text { diameter } \\
\text { ratio } \\
(\text { HDR })\end{array}$ & $\begin{array}{c}\text { Stem } \\
\text { volume } \\
(\mathrm{STV})\end{array}$ \\
\hline \multirow[t]{3}{*}{0} & $\mathrm{C}$ & $100.0(0.0)$ & $143(4)$ & $2.6(0.1)$ & $25.9(0.9)$ & - & - & - & $54.3(1.0)$ & - \\
\hline & $\mathrm{BR}$ & $100.0(0.0)$ & $152(4)$ & $2.6(0.1)$ & $27.6(0.9)$ & - & - & - & $59.9(1.0)$ & - \\
\hline & $P$ value & & 0.2146 & 0.7408 & 0.1783 & - & - & - & 0.144 & - \\
\hline \multirow[t]{3}{*}{1} & $\mathrm{C}$ & $98.6(1.7)$ & $184(4)$ & $3.1(0.1)$ & $28.1(1.3)$ & - & - & - & $58.3(0.9)$ & 0.0008 \\
\hline & $\mathrm{BR}$ & $93.8(1.7)$ & $185(5)$ & $3.2(0.1)$ & $25.7(1.3)$ & - & - & - & $55.2(1.0)$ & 0.0011 \\
\hline & Pvalue & 0.133 & 0.9167 & $0.7561^{\star}$ & 0.0455 & - & - & - & 0.3647 & $0.911^{*}$ \\
\hline \multirow[t]{3}{*}{3} & $\mathrm{C}$ & $94.4(1.7)$ & $239(7)$ & $3.9(0.1)$ & $32.0(1.2)$ & $116(3)$ & $215(7)$ & $89.2(0.7)$ & $62.0(1.0)$ & 0.0014 \\
\hline & $\mathrm{BR}$ & $90.3(1.7)$ & $244(7)$ & $4.6(0.1)$ & $35.1(1.3)$ & $120(3)$ & $220(7)$ & $88.6(0.8)$ & $54.4(1.0)$ & 0.0022 \\
\hline & P value & 0.182 & 0.639 & $0.1185^{\star}$ & 0.3342 & $0.7988^{\star}$ & 0.6224 & 0.6755 & $0.1224^{\star}$ & $0.1497^{\star}$ \\
\hline \multirow[t]{3}{*}{5} & $\mathrm{C}$ & $91.0(1.2)$ & $304(9)$ & $4.8(0.1)$ & $34.0(1.0)$ & $142(4)$ & $267(9)$ & $86.5(0.9)$ & $64.3(1.1)$ & 0.0026 \\
\hline & $\mathrm{BR}$ & $90.3(1.2)$ & $322(9)$ & $5.9(0.1)$ & $44.0(1.0)$ & $157(4)$ & $283(9)$ & $86.2(0.9)$ & $55.7(1.1)$ & 0.0046 \\
\hline & $P$ value & 0.718 & 0.0625 & $0.0418^{\star}$ & 0.0004 & 0.298 & 0.0749 & 0.7265 & $0.0761^{\star}$ & 0.0897 \\
\hline \multirow[t]{3}{*}{10} & $\mathrm{C}$ & $82.6(2.0)$ & 447 (17) & $6.7(0.3)$ & $35.5(2.4)$ & $179(6)$ & $372(16)$ & $81.2(1.1)$ & $67.8(1.2)$ & $\begin{array}{c}0.0070 \\
(0.0011)\end{array}$ \\
\hline & $\mathrm{BR}$ & $81.9(2.0)$ & 544(17) & $8.7(0.3)$ & $45.6(2.4)$ & $208(6)$ & $472(16)$ & $85.1(1.1)$ & $63.9(1.2)$ & $\begin{array}{c}0.0156 \\
(0.0011)\end{array}$ \\
\hline & $P$ value & 0.824 & $0.0008^{\star}$ & $0.0040^{*}$ & $0.0015^{\star}$ & $0.0373^{\star}$ & 0.0014 & 0.1653 & 0.2201 & $0.0206^{*}$ \\
\hline
\end{tabular}

no assumptions about the distribution of the residuals we used natural log transformation to address variation in the dependent variables. Applying these various approaches provided evidence to assess model fit and treatment response.

\section{Results}

\section{Douglas-fir survival, growth and stocking}

Survival did not vary with treatment in any given year and averaged greater than $90 \%$ through year 5 but declined to approximately $80 \%$ in year 10 (Table 2). Each of the surviving trees were qualitatively assessed and classified with regards to their vigour (see Simard 1993). The percentage of trees classified as good or fair generally did not differ with treatment; in year 10, however, control plots had a lower percentage of trees in good condition than did brushed plots $(7.6 \%$ vs $34.0 \% ; \mathrm{P}=0.027)$ and a greater percentage in fair condition (56.3\% vs $36.1 \%$; $\mathrm{P}=0.066$ ) (Fig. 1 ). At Mabel Lake, the percentage of trees classified as good or fair appeared less than on the other three sites (36\% vs. $76 \%, 78 \%$, and 78\%), consistent with its survival results.

Brushing increased the growth of Douglas-fir, but the effects were not significant until year 5 for stem diameter and leader length, and year 10 for height, crown diameter, crown length, and stem volume (Table 2). Average Douglas-fir diameter increased by $31 \%(+2 \mathrm{~cm})$ and height by $22 \%(+97$ $\mathrm{cm}) 10$ years after brushing. Percent crown length and stem height: diameter ratios were unaffected by brushing in any given year. Douglas-fir crown size was larger in the brushed plots (crown width, crown length). While brushing increased heights of Douglas-fir, modal heights of birch were always greater, except for the brushed plots in year 1 and, possibly, year 3 (Fig. 2). Differences in average height increments between brushed and control Douglas-fir tended to increase over time. Mean height increment was greater in birch (modal height increment) than in Douglas-fir in both brushed and control plots through year 5; height increments averaged from years 5 through 10 were marginally greater for Douglas-fir than birch in both control $(28.6 \mathrm{vs} .20 .0 \mathrm{~cm})$ and brushed ( 44.4 vs. $40.0 \mathrm{~cm}$ ) plots.

Average year 10 conifer densities ranged from 1169 (Mabel Lake) to 5206 (Enterprise Creek) sph and did not differ between control and brushed treatments $(P=0.8627)$. Compared to the control plots, brushed plots had a significantly greater percentage of Douglas-fir leaders well above the surrounding vegetation and significantly fewer trees overtopped by competing vegetation in years $1,3,5$, and 10 (Fig. 3). By year 10, 16\% and $47 \%$ of the Douglas-fir were free of broadleaf competition in the control and brushed plots respectively, with overtopped status at $62 \%$ and $26 \%$ for the control and brushed plots.

\section{Broadleaf responses}

Across sites and treatments, birch was the dominant component of deciduous broadleaved trees. In year 10, birch accounted for approximately $89 \%$ of deciduous broadleaved stems and $95 \%$ of deciduous broadleaved canopy cover. The percentage of deciduous broadleaved stems which were birch tended to be lower at Mabel Lake (80\%); trembling aspen and bitter cherry (Prunus emarginata (Dougl. ex Hook. Eaton) were also present. Brushing decreased cover of deciduous broadleaved trees in year $1(\mathrm{p}=0.0310)$, but the effects did not persist into years 5 and 10 (Table 3 ). In contrast, brushing 


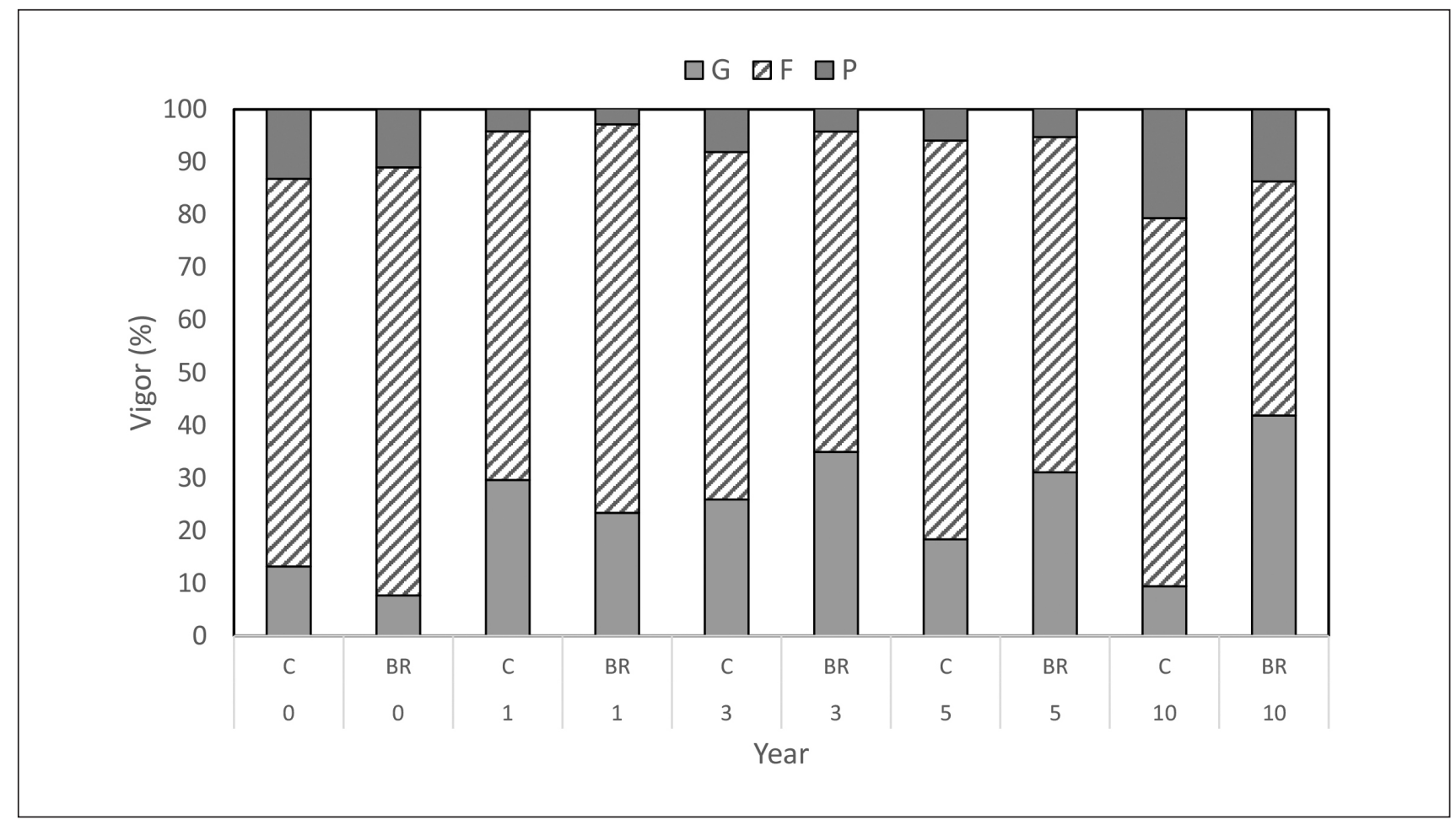

Fig. 1 Percentage of surviving Douglas-fir in different vigor classes (Simard 1993) in control (C) and brushed (BR) plots 0, 1, 3, 5 and 10 years after treatment; abbreviations: P - poor; F - fair; G - good

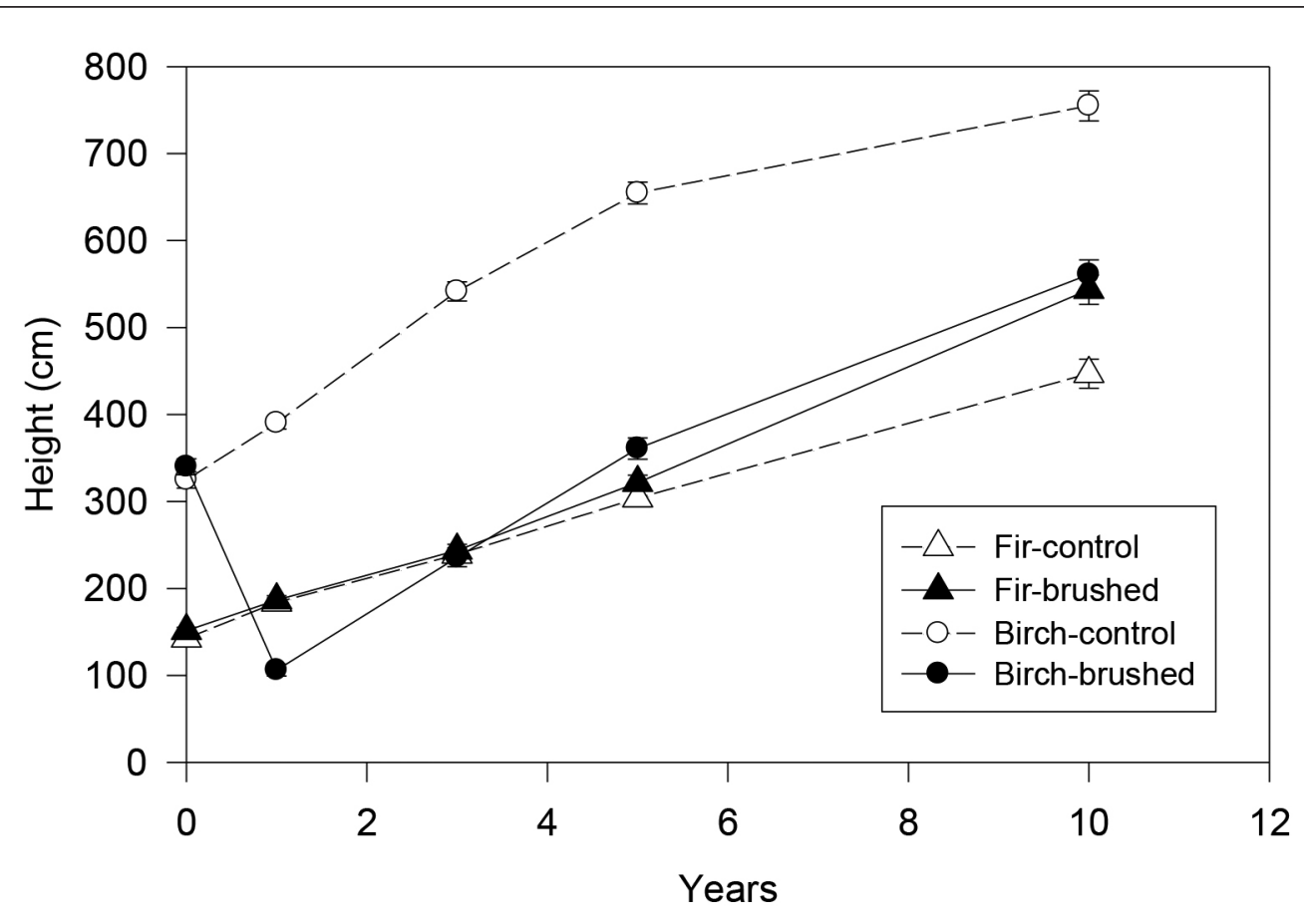

Fig. 2 Mean heights of Douglas-fir and paper birch over time in response to brushing treatments 


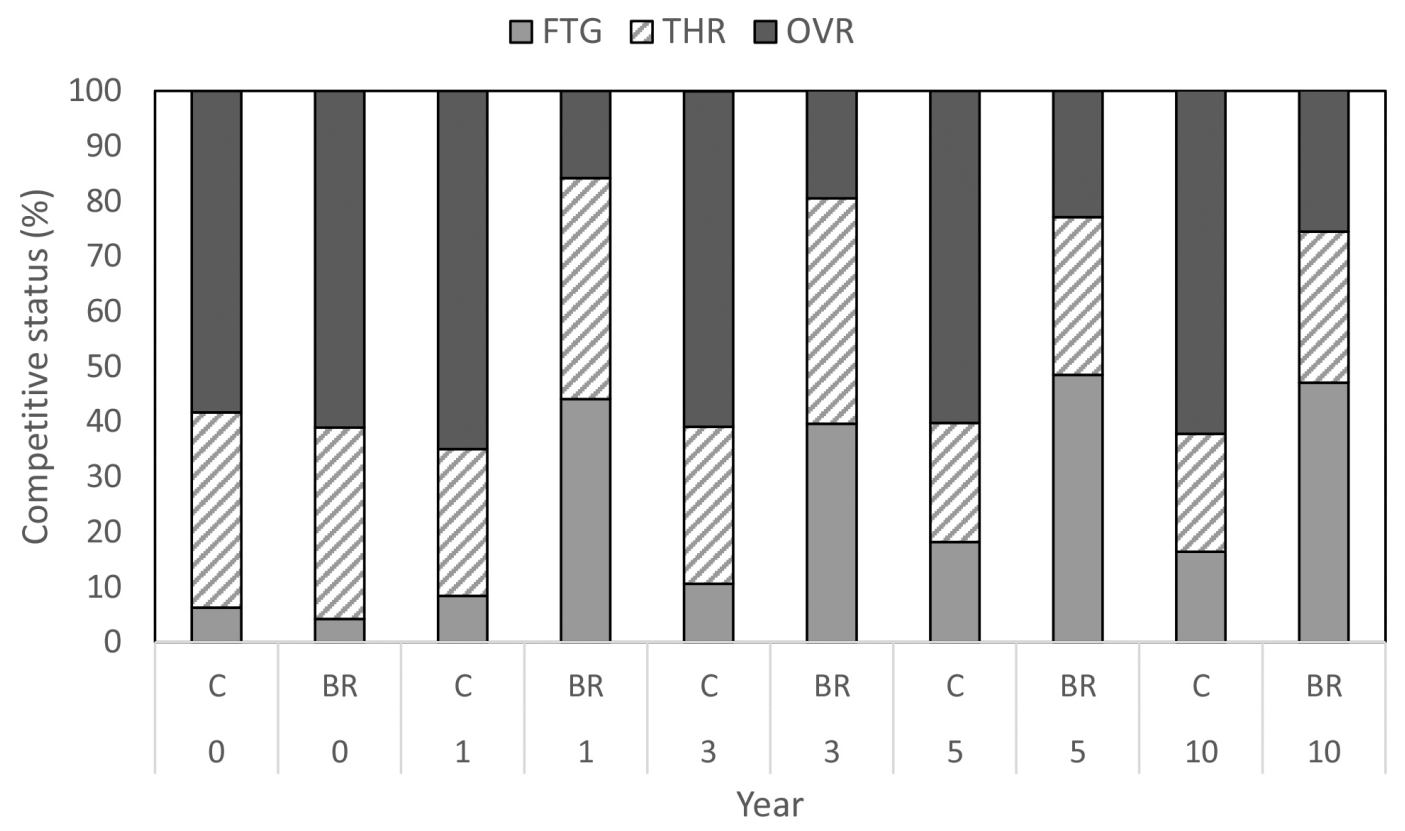

Fig. 3 Competitive status (Simard 1993) of Douglas-fir 0, 1, 3, 5 and 10 years after treatments in control (C) and brushed (BR) plots; abbreviations: OVR - overtopped; THR - threatened; FTG - free of competing vegetation

reduced modal heights of all broadleaved trees in years 1,3 , 5 , and 10 ( $\mathrm{p} \leq 0.02)$. Hence, modal heights of all broadleaf trees remained shorter in brushed plots compared to controls. There was no difference in broadleaf density between brushed and untreated control plots 10 years post brushing $(\mathrm{p}=0.2079)$.

\section{Predicting Douglas-fir size from broadleaf abundance}

Linear and non-linear relationships describing Douglas-fir size from broadleaf abundance measures were explored using all the DB data and, boundary line subsets for equal sized (Table 4) and equal tree number intervals (results not shown). Both boundary line approaches provided similar results. In general, the linear relationships between Douglasfir 10-year height and diameter over competing broadleaf density (using all data for birch or all broadleaves) were significant but weak ( $\left.\mathrm{R}^{2} \mathrm{adj}\right)$. Using the boundary line datasets containing only maximum Douglas-fir size (by interval) increased the correlations significantly with the best correlations found with all broadleaf density rather than birch alone (Table 4, Fig. 4a \& 4b). Linear predictions indicated brushed year 10 Douglas-fir were taller and larger for a given broadleaf density than control trees and the differences increased at higher densities.

The use of the exponential decline model $y=a e^{(-b x)}$ (eq. 1) to predict year 10 Douglas-fir diameters and heights (y) using $\mathrm{CRH}$ or DRH (x) abundance measures improved the predictive ability ( $\left.\mathrm{R}^{2} \mathrm{adj}\right)$ compared to the linear approach (results not shown). Boundary line analysis (using eq.1) improved predictions explaining $63 \%$ to $90 \%$ of the variation in year 10 Douglas-fir heights and diameters (Table 4). The exponential decline in Douglas-fir size with increasing CRH and DRH (Fig. 4) varied by treatment. When all broadleaf data were used, the eq. 1 intercepts (coefficient $a$ ) indicated optimal Douglas-fir diameter was $1.9-2.4 \mathrm{~cm}$ and height $93.7-95.8$ $\mathrm{cm}$ larger for the brushed versus the control Douglas-fir however, when the boundary line subset data was used, the brushing treatment difference increased to $4.6-6.4 \mathrm{~cm}$ for optimal diameter and $106-241.6 \mathrm{~cm}$ for optimal height (CRH and $\mathrm{DRH})$. Equation 1 coefficient $b$ results suggested there was an apparent change in the rate of decline with type of database used (all broadleaves or, boundary line) and the competition measure (CRH or DRH). The brushing treatment rate of decline for diameter and height was 2.3 and 2.1 times respectively that of the controls when CRH was used but apparently unchanged with DRH (0.8 and 1.1 times respectively that of the controls). The Fig. 4e \& 4 f plot of DRH-dependent Douglas-fir diameter or height and accompanying boundary line regressions show treatment differences noticeable only at DRH values $<100$. For CRH, Douglas-fir diameter and height were noticeably greater in the brushed plots only at the lowest CRHs as indicated by the boundary line regressions (for example < 50, Fig. 4c \& 4d).

Quantile regression (QR) results provided additional Douglas-fir treatment response details by size distribution. Covariate coefficient parameters (with $95 \%$ confidence limits) estimated the relative brushing treatment impact across the quantile levels ( $\mathrm{QL} ; 0$ to 1 ) where $\mathrm{QL}$ represents the cumulative distribution of the Douglas-fir growth variables, conditional on the competition level (Fig. 5). Plots of the parameter estimates indicated where along the Douglas-fir size distribution, the brushing treatment was not significant and, where brushed trees were significantly taller or larger relative to the untreated control trees for the $\mathrm{CRH}$ and DRH competition indices (density results not shown). For year 10 Douglas-fir, the brushed trees were significantly larger (15\% 
Table 3. Cover and modal heights of competing vegetation in control and brushed plots $0,1,3,5$, and 10 years after treatment. Data shown are least squares means [+ s.e.] of untransformed data

\begin{tabular}{|c|c|c|c|c|c|c|c|}
\hline \multirow[b]{2}{*}{ Year } & \multirow[b]{2}{*}{ Treatment } & \multicolumn{3}{|c|}{ Cover (\%) } & \multicolumn{3}{|c|}{ Modal height (cm) } \\
\hline & & All & DB & Birch & All & DB & Birch \\
\hline \multirow[t]{3}{*}{0} & $\mathrm{C}$ & 72.7 & 16.3 & 14.2 & $18610)$ & $323(9)$ & $325(10)$ \\
\hline & $\mathrm{BR}$ & 72.5 & 21.2 & 19 & $192(10)$ & $348(9)$ & $340(9)$ \\
\hline & $P$ value & 0.888 & $0.086^{*}$ & $0.063^{*}$ & 0.833 & 0.053 & 0.216 \\
\hline \multirow[t]{3}{*}{1} & $\mathrm{C}$ & 62.2 & 15.8 & 13.9 & $226(9)$ & $400(7)$ & $390(7)$ \\
\hline & $\mathrm{BR}$ & 55.9 & 9.3 & 7.8 & $81(9)$ & $108(7)$ & $106(7)$ \\
\hline & $P$ value & $0.079^{\star *}$ & $0.0310^{*}$ & $0.090^{*}$ & $0.020^{*}$ & $0.007^{\star}$ & $0.006^{\star}$ \\
\hline \multirow[t]{3}{*}{3} & $\mathrm{C}$ & 80.4 & 23.2 & 21.5 & $373(14)$ & $539(11)$ & $516(13)$ \\
\hline & $\mathrm{BR}$ & 77 & 18 & 16.8 & $122(15)$ & $241(11)$ & $218(13)$ \\
\hline & P value & $0.290^{\star *}$ & $0.691^{*}$ & $0.907^{*}$ & $0.014^{*}$ & $0.019^{*}$ & $0.025^{\star}$ \\
\hline \multirow[t]{3}{*}{5} & $\mathrm{C}$ & 86.2 & 29.9 & 27.6 & $516(16)$ & $654(13)$ & $655(13)$ \\
\hline & $\mathrm{BR}$ & 86.4 & 24.8 & 23.5 & $259(16)$ & $363(12)$ & $361(12)$ \\
\hline & P value & $0.977^{\star \star}$ & $0.855^{\star}$ & $0.704^{\star}$ & $0.065^{\star}$ & $0.007^{\star}$ & $0.008^{*}$ \\
\hline \multirow[t]{3}{*}{10} & $\mathrm{C}$ & 85.8 & 30.5 & 28.3 & $546(21)$ & $816(18)$ & 755 (17) \\
\hline & $\mathrm{BR}$ & 86.0 & 24.5 & 23.5 & $316(21)$ & 573 (18) & 561 (17) \\
\hline & $P$ value & $0.733^{\star *}$ & $0.856^{*}$ & $0.892^{*}$ & 0.051 & 0.004 & 0.080 \\
\hline
\end{tabular}

${ }^{*}$ indicates probability value $(P$ value $)$ is for Ln-transformed data

${ }^{*}$ indicates $P$ value is for arcsine transformed data. Vegetation groups are ALL, deciduous broadleaved trees $(\mathrm{DB})$ and birch. $P$ values $\leq 0.05$ bolded

to $24 \%$ ) in diameter for quantiles $>0.45$ (45\%) when CRH was used (Fig. 5a). That is, only the top 55\% of the brushed Douglas-fir distribution had significantly larger diameters than those found in the untreated control. For DRH, 85\% of the brushed Douglas-fir trees had diameters 25\% to $39 \%$ greater than the control trees (QL >0.15) (Fig. 5c). Heights of brushed treatment Douglas-fir were greater (10\% to $16 \%)$ at $\mathrm{QL}>85 \%$ for $\mathrm{CRH}$ and $11 \%$ to $22 \%$ greater at QL > 20\% for DRH (Fig. 5b \& 5d).

\section{Discussion}

Young conifer plantations in British Columbia are often brushed to ensure adequate survival and growth of desired crop trees to meet legislated free growing standards (BC MOF 2007; Appendix 9) where a free growing stand is defined as "a stand of healthy trees of a commercially valuable species, the growth of which is not impeded by competition from plants, shrubs and other trees" (BC MFLNRO 2015). Within this context we have assessed planted Douglas-fir response to manual brushing of birch and broadleaf competition over 10 years using the research-based evaluation procedures of PROBE (Simard 1993).

\section{Douglas-fir survival and growth}

In this study, survival of Douglas-fir did not significantly increase with brushing 10 years post treatment. Survival (and vigor) after 10 years was low at the Mabel Lake site (47\%) whereas survival at Enterprise Creek, Johnson Lake and Champion Creek all exceeded 90\%. Simard et al. (2001) reported on three of the four sites we have reported here (Mabel Lake, Enterprise Creek and Johnson Lake), that Douglas-fir mortality was primarily due to infection by A. ostoyae with a significant increase in mortality noted in brushed
Douglas-fir one-year post treatment but not thereafter. Baleshta et al. (2015) reported from other BC southern interior sites that Douglas-fir mortality, post birch thinning, showed an increase in A. ostoyae mortality only to year two (Baleshta et al. 2005) with no significant treatment differences noted at year 5. Simard et al. (2005) indicated brushing increased Douglas-fir $A$. ostoyae related mortality through three years, but not through five years. It appears that in the longer-term ( $>2-3$ years post treatment) Douglas-fir mortality is not directly related to birch competition, nor brushing activities and that the impacts of $A$. ostoyae on survival (and growth) are due to local incipient factors influencing Armillaria spread (Baleshta et al. 2015).

In general, the growth of Douglas-fir was found to benefit from brushing, but the treatment effects were not significant until year 5 for diameter and leader length and, year 10 for height and crown size. Growth responses through year 5 across the four sites were generally consistent with those previously reported for the three oldest sites; diameter increased $23 \%$ over 5 years, but $14 \%$ across the three oldest sites (Simard et al. 2001). The absolute increase in diameter through five years with brushing $(1.1 \mathrm{~cm})$ was found consistent with responses in Baleshta et al. (2015). By year 10, the diameter response had increased to $31 \%$ with height $22 \%$ greater for the brushed treatment. These observations indicate that relative and absolute growth increases with brushing increased between years 5 and 10 consistent with other published observations of improved growth in young Douglas-fir to competition removal treatments (Knowe et al. 2005, Newton and Cole 2008). These observations reaffirm the importance of long-term measurements for confirming whether shorter-term responses develop and persist or disappear. 
Table 4. Regression equations relating year 10 Douglas-fir heights $(H)$ and diameters (D) to (a) density (sph) and, (b) competition indices CRH and DRH of birch and all deciduous broadleaved (DB) trees (All p-values $\leq 0.003$ unless otherwise noted). Equations are shown for the controls (C) and brushed (BR) plots for all subplots and for boundary line subplots of equal bin intervals. Linear models were fit to growth vs. density data; exponential decay equations $\left.\left(y=a e^{[-b x}\right]\right)$ were fit to growth vs $C R H$ and DRH data.

\begin{tabular}{|c|c|c|c|c|c|c|c|c|c|}
\hline (a) & Data & Species & Treatment & Measure & Model & $\mathbf{R}^{2}$ adj & RMSE & P value & $\mathbf{n}$ \\
\hline \multirow{16}{*}{ Density (sph) } & \multirow[t]{4}{*}{ All } & Birch & $\mathrm{C}$ & $\mathrm{H}$ & $\mathrm{H}=437.351-0.0152 \mathrm{sph}$ & 0.05 & 148.82 & 0.0245 & 87 \\
\hline & & Birch & $\mathrm{C}$ & $\mathrm{D}$ & $\mathrm{D}=6.65834-0.00024 \mathrm{sph}$ & 0.05 & 2.27 & 0.0179 & 87 \\
\hline & & Birch & $\mathrm{BR}$ & $\mathrm{H}$ & $\mathrm{H}=515.343-0.00859 \mathrm{sph}$ & 0.03 & 186.75 & 0.0565 & 84 \\
\hline & & Birch & $\mathrm{BR}$ & $\mathrm{D}$ & $\mathrm{D}=8.23369-0.00009 \mathrm{sph}$ & 0.003 & 3.28 & 0.2747 & 84 \\
\hline & \multirow[t]{4}{*}{ Boundary } & Birch & $\mathrm{C}$ & $\mathrm{H}$ & $\mathrm{H}=556.059-0.0266 \mathrm{sph}$ & 0.17 & 144.86 & 0.0078 & 35 \\
\hline & & Birch & $\mathrm{C}$ & $\mathrm{D}$ & $\mathrm{D}=8.7904-0.00049 \mathrm{sph}$ & 0.27 & 2.08 & 0.0009 & 35 \\
\hline & & Birch & $\mathrm{BR}$ & $\mathrm{H}$ & $\mathrm{H}=633.509-0.0160 \mathrm{sph}$ & 0.19 & 160.55 & 0.002 & 43 \\
\hline & & Birch & $\mathrm{BR}$ & $\mathrm{D}$ & $\mathrm{D}=10.5731-0.00025 \mathrm{sph}$ & 0.14 & 2.99 & 0.0073 & 43 \\
\hline & \multirow[t]{4}{*}{ All } & DB & $\mathrm{C}$ & $\mathrm{H}$ & $\mathrm{H}=489.662-0.0180 \mathrm{sph}$ & 0.07 & 167.06 & 0.0027 & 119 \\
\hline & & DB & $\mathrm{C}$ & $\mathrm{D}$ & $\mathrm{D}=7.25806-0.00028 \mathrm{sph}$ & 0.08 & 2.35 & 0.0009 & 119 \\
\hline & & DB & $\mathrm{BR}$ & $\mathrm{H}$ & $\mathrm{H}=593.894-0.01364 \mathrm{sph}$ & 0.06 & 209.40 & 0.0033 & 118 \\
\hline & & $\mathrm{DB}$ & $\mathrm{BR}$ & $\mathrm{D}$ & $\mathrm{D}=9.2733-0.00014 \mathrm{sph}$ & 0.02 & 3.59 & 0.07 & 118 \\
\hline & \multirow[t]{4}{*}{ Boundary } & DB & $\mathrm{C}$ & $\mathrm{H}$ & $\mathrm{H}=709.704-0.04334 \mathrm{sph}$ & 0.41 & 149.45 & $<0.0001$ & 40 \\
\hline & & DB & $\mathrm{C}$ & $\mathrm{D}$ & $\mathrm{D}=10.2932-0.00063 \mathrm{sph}$ & 0.51 & 1.90 & $<0.0001$ & 40 \\
\hline & & DB & $\mathrm{BR}$ & $\mathrm{H}$ & $\mathrm{H}=799.786-0.02786 \mathrm{sph}$ & 0.38 & 174.85 & $<0.0001$ & 49 \\
\hline & & DB & $\mathrm{BR}$ & $\mathrm{D}$ & $\mathrm{D}=13.0378-0.00041 \mathrm{sph}$ & 0.29 & 3.15 & $<0.0001$ & 49 \\
\hline (b) & Data & Species & Treatment & Measure & a & $-\mathbf{b}$ & $\mathbf{R}^{2}$ adj & RMSE & $\mathbf{n}$ \\
\hline \multirow[t]{16}{*}{ CRH } & \multirow[t]{4}{*}{ All } & Birch & $\mathrm{C}$ & $\mathrm{H}$ & 564.1 & 0.00374 & 0.37 & 137.38 & 109 \\
\hline & & Birch & $\mathrm{C}$ & $\mathrm{D}$ & 8.159 & 0.00348 & 0.34 & 2.0 & 109 \\
\hline & & Birch & $\mathrm{BR}$ & $\mathrm{H}$ & 674.4 & 0.00788 & 0.28 & 183.15 & 114 \\
\hline & & Birch & $\mathrm{BR}$ & $\mathrm{D}$ & 10.761 & 0.00763 & 0.23 & 3.18 & 114 \\
\hline & \multirow[t]{4}{*}{ Boundary } & Birch & $\mathrm{C}$ & $\mathrm{H}$ & 799.059 & 0.0047 & 0.83 & 93.05 & 24 \\
\hline & & Birch & $\mathrm{C}$ & $\mathrm{D}$ & 12.332 & 0.0046 & 0.78 & 1.55 & 23 \\
\hline & & Birch & $\mathrm{BR}$ & $\mathrm{H}$ & 1100.568 & 0.0107 & 0.86 & 126.43 & 14 \\
\hline & & Birch & $\mathrm{BR}$ & $\mathrm{D}$ & 18.776 & 0.0126 & 0.90 & 1.63 & 14 \\
\hline & \multirow[t]{4}{*}{ All } & DB & $\mathrm{C}$ & $\mathrm{H}$ & 590.641 & 0.0038 & 0.44 & 130.87 & 111 \\
\hline & & DB & $\mathrm{C}$ & $\mathrm{D}$ & 8.363 & 0.0032 & 0.38 & 1.94 & 111 \\
\hline & & DB & $\mathrm{BR}$ & $\mathrm{H}$ & 686.421 & 0.0078 & 0.33 & 176.70 & 115 \\
\hline & & DB & $\mathrm{BR}$ & $\mathrm{D}$ & 10.838 & 0.0072 & 0.25 & 3.13 & 115 \\
\hline & \multirow[t]{4}{*}{ Boundary } & DB & $\mathrm{C}$ & $\mathrm{H}$ & 871.194 & 0.0056 & 0.78 & 116.18 & 26 \\
\hline & & DB & $\mathrm{C}$ & $\mathrm{D}$ & 12.454 & 0.0047 & 0.74 & 1.79 & 26 \\
\hline & & DB & $\mathrm{BR}$ & $\mathrm{H}$ & 1112.785 & 0.0115 & 0.81 & 150.97 & 15 \\
\hline & & DB & $\mathrm{BR}$ & $\mathrm{D}$ & 18.869 & 0.0123 & 0.86 & 2.00 & 15 \\
\hline \multirow[t]{16}{*}{ DRH } & \multirow[t]{4}{*}{ All } & Birch & $\mathrm{C}$ & $\mathrm{H}$ & 495.434 & 0.0067 & 0.40 & 116.92 & 85 \\
\hline & & Birch & $\mathrm{C}$ & $\mathrm{D}$ & 7.479 & 0.0066 & 0.35 & 1.87 & 85 \\
\hline & & Birch & $\mathrm{BR}$ & $\mathrm{H}$ & 565.981 & 0.0061 & 0.32 & 155.19 & 80 \\
\hline & & Birch & BR & $\mathrm{D}$ & 8.877 & 0.0044 & 0.18 & 2.93 & 80 \\
\hline & \multirow{4}{*}{ Boundary } & Birch & $\mathrm{C}$ & $\mathrm{H}$ & 704.142 & 0.0093 & 0.74 & 100.81 & 25 \\
\hline & & Birch & $\mathrm{C}$ & $\mathrm{D}$ & 10.370 & 0.0088 & 0.72 & 1.50 & 25 \\
\hline & & Birch & $\mathrm{BR}$ & $\mathrm{H}$ & 756.036 & 0.0074 & 0.66 & 143.83 & 22 \\
\hline & & Birch & $\mathrm{BR}$ & $\mathrm{D}$ & 13.535 & 0.0082 & 0.63 & 2.61 & 22 \\
\hline & \multirow[t]{4}{*}{ All } & DB & $\mathrm{C}$ & $\mathrm{H}$ & 559.420 & 0.0073 & 0.41 & 135.27 & 111 \\
\hline & & DB & $\mathrm{C}$ & $\mathrm{D}$ & 8.075 & 0.0068 & 0.37 & 1.95 & 111 \\
\hline & & DB & $\mathrm{BR}$ & $\mathrm{H}$ & 653.108 & 0.0081 & 0.33 & 176.87 & 115 \\
\hline & & DB & $\mathrm{BR}$ & $\mathrm{D}$ & 9.991 & 0.0055 & 0.19 & 3.24 & 115 \\
\hline & \multirow[t]{4}{*}{ Boundary } & DB & $\mathrm{C}$ & $\mathrm{H}$ & 851.033 & 0.0106 & 0.80 & 107.36 & 29 \\
\hline & & $\mathrm{DB}$ & $\mathrm{C}$ & $\mathrm{D}$ & 11.611 & 0.0097 & 0.69 & 1.78 & 30 \\
\hline & & DB & BR & $\mathrm{H}$ & 957.019 & 0.0108 & 0.74 & 151.93 & 26 \\
\hline & & DB & $\mathrm{BR}$ & $\mathrm{D}$ & 16.171 & 0.0092 & 0.71 & 2.63 & 26 \\
\hline
\end{tabular}



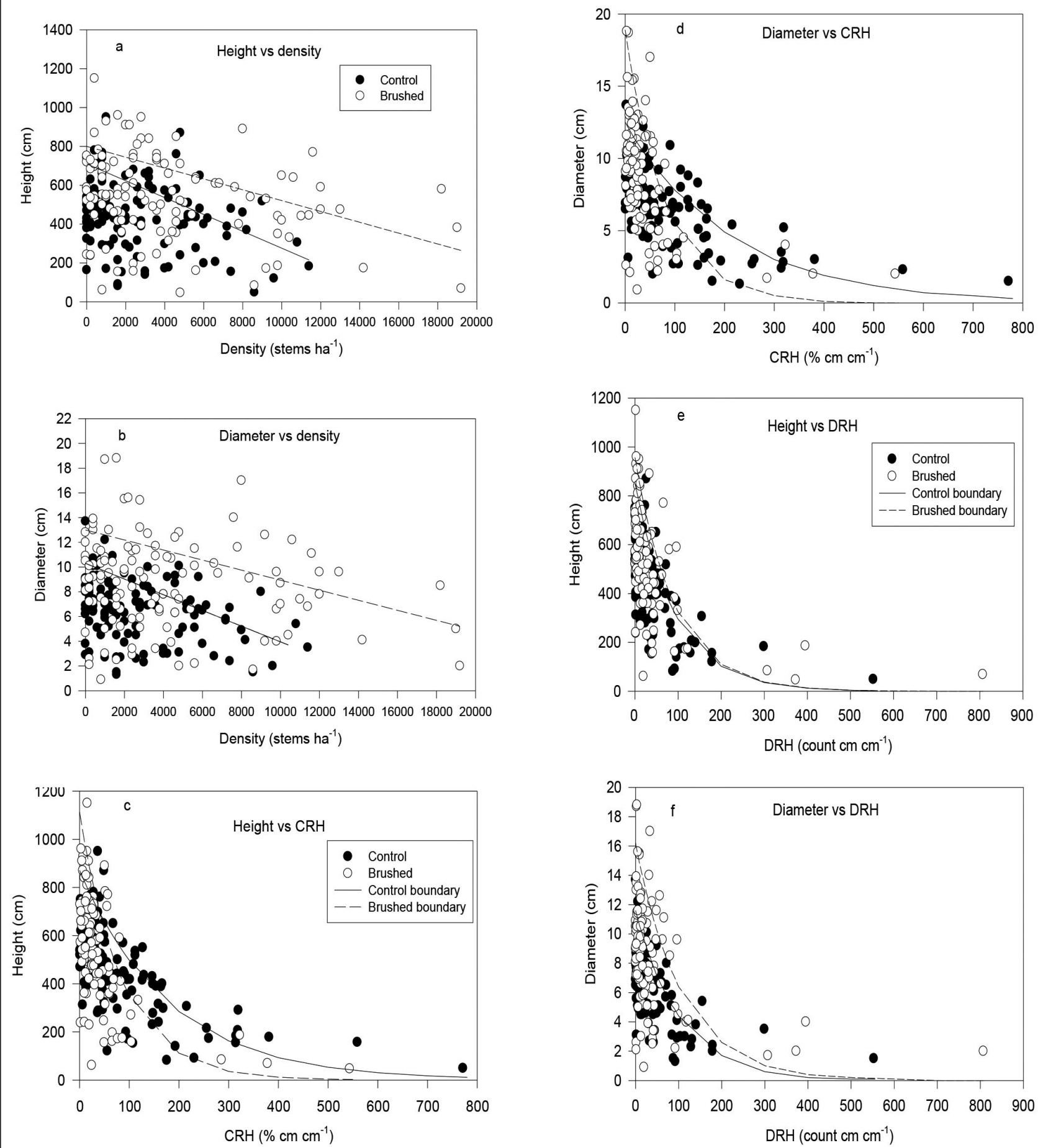

Fig. 4 Year 10 (a) height and (b) diameter of Douglas-fir in relation to density of deciduous broadleaved trees in control and brushed treatments; all data shown; regression lines are fit to boundary data. Year 10 (c) height and (d) diameter of Douglas-fir in relation to $\mathrm{CRH}$ of deciduous broadleaved trees in control and brushed treatments; all data shown; regression lines are fit to boundary data. 10 (e) height and (f) diameter of Douglas-fir in relation to DRH of deciduous broadleaved trees in control and brushed treatments; all data shown; regression lines are fit to boundary data (see text and Table 4) 


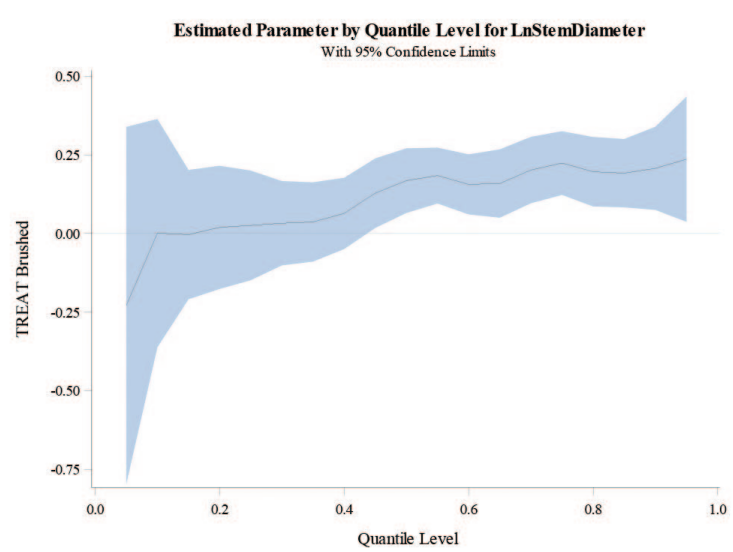

a)

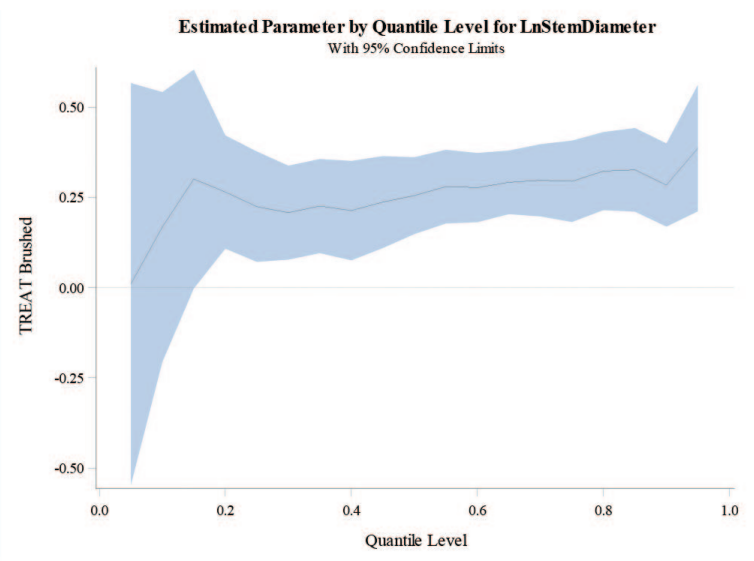

c)

Fig. 5 Estimated quantile covariate coefficients for brushing treatment difference (TREAT Brushed) relative to contol by quantile level for Douglas-fir at year 10; graphic output from SAS (Proc quantreg) using all broadleaved data with shaded areas representing 95\% confidence limits for natural log transformed (Ln) Douglas-fir; (a) diameter with $\mathrm{CRH}$, (b) height with $\mathrm{CRH}$, (c) diameter with $\mathrm{DRH}$ and, (d) height with $\mathrm{DRH}$

\section{Broadleaf response}

Manual brushing of birch often induces re-sprouting and an increase in the number of stems (Peterson et al. 1997; Simard et al. 2005). In this study, brushing reduced the height and cover of birch and other broadleaves, at least in the short term. At year 10, we saw a relatively large variation in broadleaf density up to $11000 \mathrm{sph}$ in the control plots and 19 $000 \mathrm{sph}$ in the brushing treatment (Fig. 4). Simard and Vyse (2006) indicated broadleaf densities above $400 \mathrm{sph}$ will result in suppressed Douglas-fir growth potential, conditions which were frequently noted across all four sites. The height of the regenerating birch (and other broadleaves) post brushing remained significantly shorter than those in the control plots over the entire 10-year assessment period; however, broadleaf cover was found to rapidly recover such that no significant treatment difference was noted at or after year 3 . This is contrary to the observations of Simard et al. (2005) where manual cutting of aspen and birch resulted in significant cover reductions over 5 years despite high rates of sprouting.

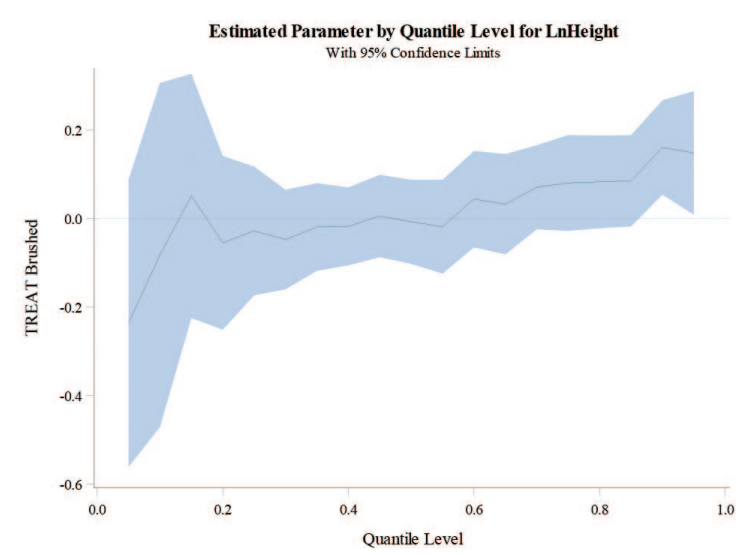

b)

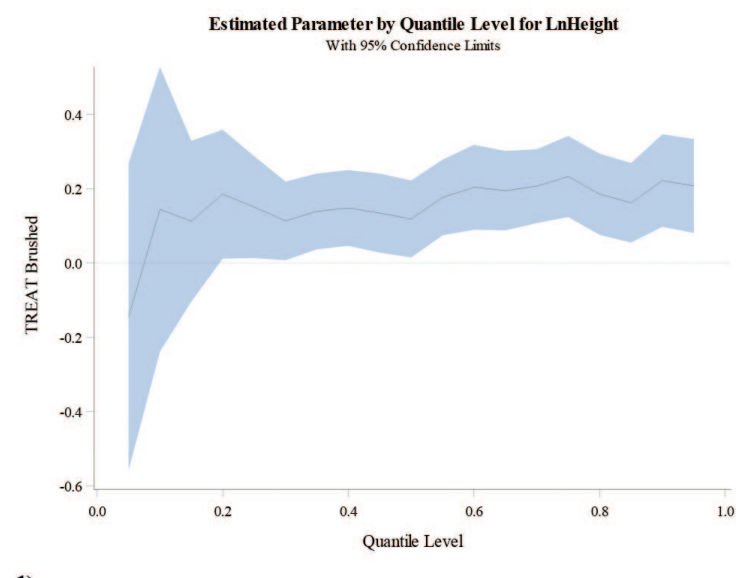

d) 
attaining Douglas-fir growth potential requires effective, early vegetation control providing unfettered growing space and resources to allow for rapid crop tree growth.

Following the approach suggested by Simard et al. (2001), we used nonlinear regression (eq. 1) to improve the prediction of 10-year crop tree performance using the competition indices $\mathrm{CRH}$ and $\mathrm{DRH}$. The improvement in predictive ability ( $\mathrm{R}^{2} \mathrm{adj}$ ) was not unexpected; both $\mathrm{CRH}$ and $\mathrm{DRH}$ incorporate neighbour competition relative height, a competition measure found well correlated with crop tree performance (Daniels et al. 1986, Simard and Sachs 2004). Broadleaf tree density alone, as a measure of competition, does not accurately account for spatial variation, canopy crowding or relative size (Zeide 2002). Both CRH and DRH are a tree level compilation of broadleaf cover or density with relative height where relative height represents the vertical dimension, modifying the two-dimensional cover or density estimates by taking account the variation in "competitive status" (Fig. 3) or vertical canopy competition. An alternative broadleaf competition measure that considers only broadleaf densities that are as tall as or taller than the crop trees, has been promoted to integrate with BC's free growing regulations (Heineman et al. 2009; Newsome et al. 2012). However, this approach does not consider the "smaller than" component of broadleaf competition, stand density and canopy composition (Harper 2017) and, effectively truncates the vertical dimension of the competition neighbourhood and the lower competition intensity distribution where maximum response is correlated (Wagner 2000; Simard et al. 2005; Harper 2015).

\section{Competition assessment using nonlinear boundary line and quan- tile regression}

Nonlinear boundary line predictions of Douglas-fir growth provided a quantifiable methodology for addressing the hypothetical threshold relationship where broadleaf competition constricts crop tree growth as described in Simard et al. (2001) where ceiling functions were defined, and threshold competition levels identified qualitatively. The boundary line models used here were based on tightly constrained and subjectively selected data subsets or bins (maximum Douglas-fir tree values per competition interval). The boundary line models predicted potential growth at a given level of broadleaf competition and indicated how crop tree growth may optimally respond, whereas the use of all the data indicated how average trees responded without providing any indication of what factors may be limiting performance.

We used an exponentially declining model like that used to describe lodgepole pine response to increasing broadleaf competition (Simard et al. 2005, Harper et al. 2009). Model (eq. 1) coefficients $a$ and $b$ respectively, can be used to estimate maximum size at low competition intensity or, highlight the rate of decline (Zeide 1989; Harper 2017). The model $b$ coefficients (Table 4 ) indicated the decline in Douglas-fir diameter and height with increased broadleaf competition varied with treatment (brushed or untreated) and the competition measure used (CRH vs DRH). The much steeper decline noted in the brushed Douglas-fir boundary line relative to that of the control with increasing $\mathrm{CRH}$ suggested a change in the Douglas-fir response distribution with treatment. However, this treatment response observation was not apparent with the DRH competition measure. The reason for this contrary observation is not clear and may reflect the inherent difference between broadleaf cover estimates and density.

Both the boundary line analysis and all-data scatterplots did not indicate the presence of any meaningful competition thresholds. Similar observations were noted with Douglas-fir and lodgepole pine diameter response to aspen $\mathrm{CRH}$ where visually defined maximum response thresholds were near zero (Simard et al. 2001). On average, Douglas-fir size either decreased in a linear fashion with increasing broadleaf density (boundary-line subset) or decreased exponentially with increasing CRH or DRH (boundary line and DB data sets).

The existence of a competition threshold implies that there exists no net negative effect on Douglas-fir growth from retaining competition below a certain level. In general, the single operational brushing treatment failed to eliminate or reduce broadleaf competition to a low level for at least $51 \%$ of the Douglas-fir which were assessed as overtopped or threatened after 10 years (Fig. 3). The Douglas-fir found in low competition neighbourhoods (Fig. 4) showed a wide range of size response. Clearly other factors were influencing size development. Fang et al. (2019) suggested crown light competition and nutritional factors may influence Douglas-fir diameter when found in mixture with red alder (Alnus rubra Bong.) and that neighbour distance as well as the influence of assessment plot size are important variables. Simard and Sachs (2004) suggested a critical neighbourhood distance of between $3-6 \mathrm{~m}$ for stand ages like those found in this study (15 - 19 at 10 years post brushing). It is probable that by post treatment year 10 when average birch height was $\geq 5.6 \mathrm{~m}$, the $3.99 \mathrm{~m}$ radius assessment plot was too small to account for neighbourhood influences such as canopy crowding dynamics and below ground resource competition.

Lastly, quantile regression was used to describe the year 10 brushing treatment response distribution across Douglas-fir diameter and height percentiles or quantiles above or below the conditional mean effect (noted by the horizontal " 0 " line in Fig. 5) (Koenker and Hallock 2001). Quantile regression provides a flexible approach to addressing the problem of evaluating the brushing response across the Douglas-fir population. Results suggested the brushing treatment increased Douglas-fir diameters in the top $55 \%$ or $85 \%$ of the population for $\mathrm{CRH}$ or DRH respectively. Similarly, Douglas-fir height was significantly taller in the top $15 \%$ and $80 \%$ of the brushed Douglas-fir respectively. Simply stated, the brushing treatment effect was not noticeable within the smaller Douglas-fir cohorts due to the large estimate variation (see shaded areas in Fig. 5). The brushing response significance improved within larger sized Douglas-fir. The notable difference in minimum level of significant QL (defined by the 95\% confidence limits) between CRH or DRH suggested density-based $\mathrm{DRH}$ was a more sensitive measure of broadleaf tree competition on these sites than the cover-based CRH for Douglasfir diameter and height.

\section{Brushing and stand productivity}

In keeping with similar published results on single manual brushing of deciduous broadleaf competition (Simard 1990; Heineman et al. 2009), a measurable improvement in the vigor and size of young Douglas-fir can be expected on zonal sites in the Mixed Broadleaf-Shrub Vegetation Complex. 
However, the competitive status results indicated only $47 \%$ of the brushed Douglas-fir were free growing after 10 years, an increase of only $3 \%$ since year 1 . It is clear the brushed birch and other broadleaf trees recovered quickly within the first three years after brushing; treatment effects on cover, and density were no longer significant and heights of broadleaf trees and Douglas-fir in brushed plots no longer differed. Brushing provided only an early, short term respite from the birch and broadleaf competition. The addition of birch and broadleaf density to the Douglas-fir plantations has altered crop tree size growth patterns, early competitive stand dynamics and successional trajectory (Boyden et al. 2009). It appears that to attain greater free growing and increase long term Douglas-fir productivity additional brushing or thinning treatments will be required. At the stand level, birch and broadleaf canopy occupancy will likely be at the expense of Douglas-fir growth and yield, a situation not dissimilar to that found with lodgepole pine and aspen (Harper 2015), spruce and aspen (Kabzems et al. 2016) and, loblolly pine hardwood release (Miller et al. 2003). Silviculture strategies designed to increase conifer crop tree performance and stocking, shorten regeneration delay and improve brushing efficacy must ensure effective and timely broadleaf competition removal (Comeau et al. 1999; Boateng et al. 2009; Comeau and Harper 2009). Alternatively, any philosophical or policy change in forest management objectives that allow for conifer-broadleaf mixed species stand composition must address performance expectations and stocking standards (Lieffers et al. 2008). Research is needed to understand the long-term impacts of increased density, resource use efficiency, canopy space filling and niche complementarity associated with mixed species stands (Pretzshe and Zenner 2017). The 10-year results show that although brushing improved Douglas-fir vigour and growth, the broadleaf tree densities, cover and height (predominately paper birch) were limiting the growth of a significant portion of the Douglas-fir plantations. In the longer term, without additional brushing or thinning treatment it is expected that overall stand productivity of these brushed sites will partition into broadleaf and Douglas-fir components resulting in complex stand dynamics dependent on species productivity, competition intensity, density and canopy occupancy. Also, concerns over climate change and the increased frequency of seasonal drought in southern $\mathrm{BC}$ forests have renewed interest in the potential for brushing treatments to increase the availability of soil moisture through reduced evaporative demand and soil moisture stress resulting in significant increases in survival and growth of planted Douglas-fir (Wightman et al. 2019). Douglas-fir may utilize carbon assimilated by birch and shared, possibly, through ectomycorrhizal networks (Simard et al. 1997); other resources may be shared as well (e.g., Gorzelak et al. 2015), potentially providing some resilience to stresses exacerbated under a changing climate. Continued monitoring of the long-term impacts of operational brushing on tree and stand productivity together with research on mixed species forests are essential for improving our growth and yield models (Pretzche et al. 2015) and providing foresters with the science-based information needed to objectively evaluate their silviculture regimes and forest management plans.

In conclusion, Douglas-fir management practices need to evolve in southern British Columbia to provide conditions that optimize early growth rates and shorten rotations. The results presented here indicate operational brushing broadleaf tree competition will increase growth incrementally over at least 10 years. We found no evidence to support competition thresholds for birch dominated areas. Broadleaf density needs to be managed over the long term to realize Douglas-fir growth potential. Foresters need to develop site specific performance measures and tailor cost effective silviculture regimes that account for the impacts of birch and broadleaf competition on Douglas-fir productivity.

\section{Acknowledgement}

Funding for this study was provided by the B.C. Ministry of Forests, Lands, Natural Resource Operations and Rural Development. The authors are grateful to Suzanne Simard whose vision and commitment, with the assistance of many contractors, resulted in the establishment of 96 PROBE installations across the southern interior of BC. We would also like to acknowledge the valuable comments received from several anonymous reviewers.

\section{References}

Baleshta, K.E., S.W. Simard and W.J. Roach. 2015. Effects of thinning paper birch on conifer productivity and understory plant diversity. Scand. J. For. Res. 30: 8, 699-709.

Baleshta, K. E., S.W. Simard, R.D. Guy and C.P. Chanway. 2005. Reducing paper birch density increases Douglas-fir growth rate and Armillaria root disease incidence in southern interior British Columbia. For. Ecol. Manage. 208: 1-13.

B.C. MOF. [Ministry of Forests]. 2007. Establishment to free growing guidebook. Nelson Forest Region. Rev. Ed., Version 2.3. For. Prac. Br., B.C. Min. For., Victoria, B.C. Forest Practices Code of British Columbia Guidebook. https://www2.gov.bc.ca/assets/gov/ farming-natural-resources-and-industry/forestry/silviculture/ stocking-standards/efgg/efg-nel-print.pdf

BC MFLNRO. 2015. (B.C. Ministry of Forests, Lands and Natural Resource Operations). Forest and Range Practices Act. Victoria, BC. URL: http://www.bclaws.ca/Recon/document/ID/freeside/ 00_02069_01

Boateng, J.O., J.L. Heineman, L. Bedford, G.J. Harper and A.F.L. Nemec. 2009. Long-term effects of site preparation and post planting vegetation control on Picea glauca survival, growth and predicted yield in boreal British Columbia. Scand. J. For. Res. 24: 111-129.

Boyden, S.B., P.B. Reich, K.J. Puettmann and T.R. Baker. 2009. Effects of density and ontogeny on size and growth ranks of three competing tree species. J. Ecol. 97: 277-288.

Brown, K.R. 1999. Mineral nutrition and fertilization of deciduous broadleaved trees in British Columbia. Research Branch, B.C. Min. For., Victoria, B.C. Work. Pap. 42.

Burton, P.J. 1993. Some limitations inherent to static indices of plant competition. Can. J. For. Res. 23: 2141-2152.

Chapin, F.S. III, P.R. Tryon and K. van Cleve. 1983. Influence of phosphorus supply on growth and biomass allocation of Alaskan taiga tree seedlings. Can. J. For. Res. 13: 1092-1098.

Coates D. and E. Lilles. 2013. An evaluation of the main factors affecting yield differences between single- and mixed-species stands. B.C. J. Ecosyst. Manage. 14: 122-130.

Comeau, P.G. and G.J. Harper. 2009. Effects of vegetation control treatments for release of Engelmann spruce from a mixed-shrub community in southern British Columbia - year 15 results. For. Chron. 85 (4): 583-592.

Comeau, P.G., B.S. Biring and G.J. Harper. 1999. Conifer response to brushing treatments: A summary of British Columbia data. B.C. Min. For. Res. Br. Victoria, B.C. Ext. Note 41. 
Daniels, R.F., H.E. Burkhart and T.R. Clason. 1986. A comparison of competition measures for predicting growth of loblolly pine trees. Can. J. For. Res. 16: 1230-1237.

Fang, C., P.G. Comeau, and G.J. Harper. 2019. Effects of red alder on growth of Douglas-fir and western redcedar in southwestern British Columbia. For. Ecol. Manag. 434: 244-254.

Gorzelak, M.A., A.K. Asay, B.J. Pickles, and S.W. Simard. 2015. Inter-plant communication through mycorrhizal networks mediates complex adaptive behaviour in plant communities. AoB PLANTS 7: plv050. 13 pp.

Harper, G.J. 2015. Lodgepole pine and trembling aspen mixedwoods: Growth and yield within 22 to 39 year-old pine plantations of northern interior British Columbia. For. Chron. 91(5): 502-518. Harper, G.J. 2017. Lodgepole pine and trembling aspen mixedwoods: Neighbourhood studies within 22 to 39 year old pine plantations of northern British Columbia. For. Chron. 93(3): 226-240.

Harper, G.J., M. O'Neill, P. Fielder, T. Newsome and C. Delong. 2009. Lodgepole pine growth as a function of competition and canopy light environment within aspen dominated mixedwoods of central interior British Columbia. For. Ecol. Manag. 257: 1829-1838. Harrington, C. and P.J. Courtin. 1994. Evaluation of site quality for red alder. In: The biology and management of red alder. D.E. Hibbs, D.S. DeBell, and R.F. Tarrant (Eds.). Oregon State University Press, Corvallis, Ore. pp. 141-158.

Heineman, J.L., S.W. Simard, D.L. Sachs and W.J. Mather. 2009. Trembling aspen removal effects on lodgepole pine in southern interior British Columbia: ten-year results. West. J. Appl. For. 24: 17-23. Kabzems, R., M. Bokalo, P.G. Comeau and D.A. MacIsaac. 2016. Managed mixtures of aspen and white spruce 21 to 25 years after establishment. Forests, 7: 5. 16 pp.

Klinka. K., M.C. Feller, R.N. Green, D.V. Meidinger, J. Pojar and J. Worrall. 1990. Ecological principles: applications. In: Regenerating British Columbia's forests. D.P. Lavender, R. Parish, C.M. Johnson, G. Montgomery, A. Vyse, R.A. Willis, D. Winston (editors). UBC Press, Vancouver, B.C. pp. 55-72.

Knowe, S.A., Radosevich, S.R. and Shula, R.G. 2005. Basal area and diameter distribution prediction equations for young Douglasfir plantations with hardwood competition: Coast Ranges. West. J. Appl. For. 20 (2): 77-93.

Koenker, R. and G. Bassett. 1978. Regression quantiles. Econometrica 46: 33-50.

Koenker, R. and K. Hallock. 2001. Quantile Regression: An Introduction. J. Econ. Perspect. 15: 143-156.

Lieffers, V.J., G.W. Armstrong, K.J. Stadt and E.H. Marenholtz. 2008. Forest regeneration standards: Are they limiting management options for Alberta's boreal mixedwoods? For. Chron. 84 (1): 76-82. McDonald, P.M., G.O. Fiddler and H.R. Harrison. 1994. Repeated manual release in a young plantation: effect on Douglas-fir seedlings, hardwoods, shrubs, forbs, and grasses. Res. Paper PSWRP-221. Albany, CA: Pacific Southwest Research Station, Forest Service, U.S. Department of Agriculture: 11 pp.

Meidinger, D. and J. Pojar. 1991. Ecosystems of British Columbia. B.C. Min. For., Res. Br., Victoria, B.C. Spec. Rep. Ser. 6. Available from https://www.for.gov.bc.ca/hfd/pubs/docs/srs/Srs06.pdf

Miller, J.H., B.R Zutter, S.M. Zedaker, M.B. Edwards and R.A. Newbold. 2003. Growth and yield relative to competition for loblolly pine plantations to midrotation- A southern United States regional study. South J. Appl. For. 27 (4): 237-252.

Newsome T.A., J.L. Heineman and A.F. Linnell-Nemec. 2012. Identifying and characterizing important trembling aspen competitors with juvenile lodgepole pine in three south-central British Columbia ecosystems. Int. J. For. Res. Article ID 573640.

Newton, M. and E.C. Cole. 2008. Twenty-six-year response of ponderosa pine and Douglas-fir plantations to woody competitor density in treated stands of madrone and whiteleaf manzanita. For. Ecol. Manag. 256 (3): 410-420.
Peterson, E.B., N.M. Peterson, S.W. Simard and J.R. Wang. 1997. Paper birch manager's handbook for British Columbia. For. Can. and B.C. Min. For., Victoria, B.C.

Pretzsch H. and E.K. Zenner. 2017. Toward managing mixedspecies stands: From parametrization to prescription. For. Ecosyst. 4: 19.17 pp.

Pretzsch H., D.I. Forrester and T. Rötzer. 2015. Representation of species mixing in forest growth models: A review and perspective. Ecol. Model. 313: 276-292.

Sadras, V.O., K.G.G. Cassman, P. Grassini, A.J. Hall, W.G.M. Bastiaanssen, A.G. Laborte, A.E. Milne, G. Sileshi and P. Steduto. 2015. Yield gap analysis of field crops - Methods and case studies. FAO Water Reports No. 41, Rome, Italy.

Simard, S.W. 1990. A retrospective study of competition between paper birch and planted Douglas-fir: FRDA Report No. 147. Victoria (Canada): For. Can. and B.C. Min. For. Available from: https:// www.for.gov.bc.ca/hfd/pubs/Docs/Frr/Frr147.pdf

Simard, S.W. 1993. PROBE: Protocol for operational brushing evaluations (first approximation). B.C. Min. For., Victoria, B.C., Land Manage. Rep. No. 86.

Simard S.W. and D.L. Sachs. 2004. Assessment of interspecific competition using relative height and distance indices in an age sequence of seral interior cedar-hemlock forests in British Columbia. Can. J. For. Res. 34: 1228-1240.

Simard, S. and A. Vyse. 2006. Trade-offs between competition and facilitation: A case study of vegetation management in the interior cedar-hemlock forests of southern British Columbia. Can. J. For. Res. 36: 2486-2496.

Simard S.W., D.L. Sachs, A. Vyse and L.L. Blevins. 2004. Paper birch competitive effects vary with conifer tree species and stand age in interior British Columbia forests: Implications for reforestation policy and practice. For Ecol Manage. 198: 55-74.

Simard, S.W., J.L. Heineman, W.J. Mather, D.L. Sachs and A. Vyse. 2001. Effects of operational brushing on conifers and plant communities in the southern interior of British Columbia: Results from PROBE 1991-2000. Res. Br., Min. For., Victoria, B.C. Land Manag. Handb. No. 48.

Simard, S.W., S.M. Hagerman, D.L. Sachs, J.L. Heineman and W.J. Mather. 2005. Conifer growth, Armillaria ostoyae root disease and plant diversity responses to broadleaf competition reduction in temperate mixed forests of southern interior British Columbia. Can. J. For. Res. 35: 843-859.

Simard, S.W., M.D. Jones, D.M. Durall, D.A. Perry, D.D. Myrold and R. Molina. 1997. Reciprocal transfer of carbon isotopes between ectomycorrhizal Betula papyrifera and Pseudotsuga menziesii. New Phytol. 137: 529-542.

Sit, V. and M. Poulin-Costello. 1994. Catalog of curves for curve fitting. Biometrics information handbook series. Handbook No. 4. March 1994. Res. Br., B.C. Min. For., Victoria, B.C. Available from http://www.for.gov.bc.ca/hfd/pubs/Docs/Bio/Bio04.htm

Wagner, R.G. 2000. Competition and critical-period thresholds for vegetation management decisions in young conifer stands. For. Chron. 76: 961-968.

Wagner, R.G., T.D. Petersen, D.W. Ross and S.R. Radosevich. 1989. Competition thresholds for the survival and growth of ponderosa pine seedlings associated with woody and herbaceous vegetation. New For. 3: 151-170.

Waring, R.H. and J.F. Franklin. 1979. Evergreen coniferous forests of the Pacific Northwest. Science 204: 1380-1386.

Wightman, M.G., C.A. Gonzalez-Benecke and E.J. Dinger. 2019. Interactive effects of stock type and forest vegetation management treatments on Douglas-fir seedling growth and survival - Ten-year results. Forests 10: 1002.

Zeide, B. 1989. Accuracy of equations describing diameter growth. Can. J. For. Res. 19: 1283-1286.

Zeide, B. 2002. Analysis of a concept: Stand density. J. Sustain. Forest. 14 (4): 51-62. 